\title{
ТРАНСФОРМАЦИЯ ИЗОБРАЗИТЕЛЬНОГО ИСКУССТВА:
} СУБЪЕКТИВНЫЙ ВЗГЛЯД С ПОЗИЦИИ ПОСТНЕКЛАССИЧЕСКОЙ ПСИХОЛОГИИ, ОРИЕНТИРОВАННОЙ НА ХРИСТИАНСКУЮ АНТРОПОЛОГИЮ'

\author{
М. Н. МироновА
}

\begin{abstract}
Автор, действуя в рамках постнеклассической, христиански ориентированной психологии, ставит проблему исследования психологических аспектов трансформации изобразительного искусства и пытается понять, что лежит в ее основе. Наиболее существенная трансформация связана с авангардом. Анализируя динамику изменения изобразительного стиля в хронологической последовательности на протяжении всего творчества ряда художников, стоящих у истоков авангарда, автор показывает, что в главном она соответствует обратному порядку развития изобразительных способностей ребенка. Далее анализируются такие формы «нового искусства», как инсталляция, перформанс и акционизм, и предполагается, что динамика трансформации изобразительного искусства, конечным пунктом которого они являются, соответствует обратному порядку развития воображения ребенка до самой «ранней» его стадии - с бинарными операциями, которые имеют свойство искажаться в результате деградации до абсурда и нелепостей. Обращение к принципу развития в традиционной психологии вряд ли могло бы дать какую-либо определенную оценку данным феноменам: у нее нет ответа на вопрос - куда и зачем человек должен развиваться; главное, чтобы он изменялся, делал что-либо новое. Однако эта проблема решается однозначно в психологии, ориентированной на христианскую антропологию. Любая деградация - это удаление от Бога.
\end{abstract}

\section{Василий Кандинский. Беспредметная живопись}

В. В. Кандинский - основатель абстрактной живописи. До своей первой абстрактной картины он писал в традиционном стиле. Это прекрасные пейзажи и жанровые полотна, выполненные в период до 1902 г. («Одесса. Порт», «Кохель - Водопад І», «Эскиз шлюза», «Ахтырка - Темное озеро», «Русский Витязь» и др.). Затем в его работах появился стиль «модерн» («Синий всадник», «Зеркало», «Золотой парус», «Скала» и др.). Позже он знакомится с фовизмом,

${ }^{1}$ Начало статьи см. Миронова М. Н. Трансформация изобразительного искусства: субъективный взгляд с позиции постнеклассической психологии, ориентированной на христианскую антропологию // Вестник ПСТГУ. Серия IV: Педагогика. Психология. 2017. Вып. 44. C. 134-149. 
М. Н. Миронова. Трансформация изобразительного искусства: субъективный взгляд...

изучает теософию Рудольфа Штайнера и восхищается книгами Елены Блаватской. Возможно, именно эти увлечения оказали решающее значение на выбор пути в художественном творчестве.

Кандинский начинает искать способы духовного влияния на зрителей, полагая, что наиболее эффективным является психофизическое воздействие чистых красочных сочетаний. Под влиянием фовизма у Кандинского появилось убеждение, что обычное искусство устарело и обветшало, что на смену традиционным представлениям об эстетике как критерии истинности пришли новые, связанные со степенью эмоционального воздействия. Изложенные на страницах книги Кандинского «О духовном искусстве» представления о целях и смыслах художественной деятельности отходят и от традиционных, и от христианских и приближаются к оккультным. На последнее указывает хотя бы то, что великий современник, И. Е. Репин, упрекая его за порчу таланта, говорил, что его работы «изуродованы спиритизмом».

Если мысленно расположить картины 1903-1911 гг. последовательно, то отчетливо видно, как цветовые пятна постепенно заменяют собой прорисовку элементов («Прощание», «Невеста. Русская красавица», «Веер», «Двое на лошади», «Осенний пейзаж с лодками», «Вид Мурнау с железной дорогой и замком», «Гора», «Пейзаж с фигурами и ребенком», «Мурнау. Сад», «Лошади», «Корова», «Лирическое (Лирика)» и др.). Постепенно изображения предметов и людей все более искажаются, их уже трудно распознать («Церковь в Мурнау», «Мурнау. Сад», «Все святые II», «Обнаженная», «Ангел Страшного Суда»). Теперь эти полотна называют полубеспредметными. А с точки зрения периодизации детского рисования эти изображения являются воспроизведением графического подобия окружающих объектов, предметов и персонажей, которые только обозначают их в начале стадии единичных предметных изображений.

В конце концов художник совсем отказался от сюжетного изображения («Первая абстрактная акварель», «Беспредметное» 1919 г.). Теперь его «импрессии», «импровизации» и «композиции» чаще всего не имеют названия («304», «Композиция V» и др.). В них все большее значение играют геометрические формы.

Однако «Искусство... всегда отношение. То, что воссоздано (изображение), воспринимается в отношении к тому,... что не воссоздано... Отказ от воссоздания одних сторон предмета не менее существенен, чем воспроизведение других» ${ }^{2}$.

Существует психологический тест «Весь мир» ${ }^{3}$ испытуемого просят нарисовать весь мир так, как он себе его представляет. Оказывается, что практически все психологически здоровые люди (любого возраста, любого социального положения, любого государства) обычно рисуют Землю, дома, людей и деревья (это могут быть живописные изображения или схематичные). Остальные детали рисунка сугубо индивидуальны, но именно первые четыре образа не случайны и символичны. Интерпретация картин Кандинского с этих позиций указывает на то, что абстракция искажает, а затем и пожирает все ключевые символические

${ }^{2}$ Лотман Ю. М. Лекции по структурной поэтике // Ю. М. Лотман и тартусско-московская семиотическая школа. М., 1994. С. 37.

${ }^{3}$ Аксенова Ю. А. Символы мироустройства в сознании детей. Екатеринбург, 2000. 
образы. Но именно от них зависит возможность решения проблемы человека, поднятой в работе С. Л. Рубинштейна «Человек и мир»: «...осознания... своей причастности к Миру как бесконечно целому»

Динамика изобразительных стилей художника такова: от полотен, содержащих сюжет, к полубеспредметным полотнам, серии беспредметных картин, в которых уже совсем нет сюжета, но они отличаются цветовой проработкой. Чуть позже - абстрактная живопись, в которой в начале преобладает цвет, затем - геометрические формы. Что точно соответствует обратному чередованию стадий развития художественных способностей ребенка: событийное рисование - стадия единичных предметных изображений - объектное рисование с преобладанием предметности цвета - объектное рисование с преобладанием геометрических форм. Следовательно, такая строгая последовательность не могла быть случайной. А так как в те годы еще не было известно о периодизации развития художественных способностей, нельзя говорить и о целенаправленном изменении стиля; но можно - о процессе деградации последних.

Подчеркнем еще один важнейший момент: В. Кандинскому всегда была свойственна тяга к духовным исканиям. Некоторые его картины выполнены по библейским сюжетам; на стенах квартиры висели иконы, а его кисть несколько раз создавала полотна под названием «Все святые» и «Апокалипсис». На первых картинах Кандинского присутствовали два символических изображения, которые говорили о его вполне традиционной религиозности: храм на горе и всадник, Георгий-Победоносец. Но потом эти два символа стали размываться, искажаться, потом исчезли вовсе: святых и ангелов Апокалипсиса на полотнах стало невозможно угадать в нагромождении линий и цветовых пятен.

Георгий Победоносец все же однажды вновь появился («Всадник Святой Георгий» 1915-1916 г.); думается, что он был послан Богом для того, чтобы возвратить художника на истинный путь. Но возвращения не произошло. Кандинский и далее экспериментировал с различными живописными формами, воздействующими на психику и эмоции зрителя. В этом смысле он стал жертвой главной мистификации XX в. - подмены духовного пути следования за Иисусом Христом путем психофизиологической, «плотской» духовности.

В последний период творчества (1938-1940 гг.) на картинах появляются так называемые биоморфные элементы («Небесно-голубое», «Сложное-простое», «Пестрый ансамбль» и др.), критики пишут о том, что на них «кипит жизнь». Но в контексте представленных воззрений эти картины знаменуют попытку реабилитации изобразительности, некоторое возвращение к первоначальному мастерству. Но не будем забывать о принципе необратимости регрессии! Полноценного возвращения не случилось. Абстрактная форма, особенно после периода изображения острых углов, треугольников и прямоугольников поглотила и исказила многое, что было свойственно более раннему мастеру.

Отказ от предметности оказался поворотным пунктом не только в деятельности Кандинского, но и всего изобразительного искусства. Разработав теорию абстрактной живописи, он увлек за собой последователей, усвоивших приятную

\footnotetext{
${ }^{4}$ Рубинштейн С. Л. Человек и мир. М., 1997.
} 
М. Н. Миронова. Трансформация изобразительного искусства: субъективный взгляд...

и легко осваиваемую тенденцию. Но все ли они обладали хотя бы и крохой исходного таланта первооткрывателя?

\section{Т. Маринетти. Футуризм}

Литературно-художественное направление «футуризм» создано итальянским поэтом, а впоследствии художником Филиппо Томаззо Маринетти. Являясь официальным идеологом, вождем и властным диктатором направления, в 1908 г. он издает «Манифест», в котором призывает восстать против традиций классического искусства. Маринетти провозглашает, что металл должен куда более волновать чувства художника, чем женшина; мотоцикл - более совершенное творение, чем скульптуры Микеланджело; фотоаппарат и кинокамера заменят несовершенство живописи; восхваляет войны, которые называет омолаживающей силой мира, поэтому: «нет шедевров без агрессивности». Художникифутуристы, последовавшие призыву, посвящали свои произведения самолетам, поездам, автомобилям, но в них не было места живому.

Чтобы понять особенности этого направления авангарда, обратимся к имеющимся современным исследованиям творчества русских поэтов-футуристов, так как идеи Маринетти были восприняты и претворены в полной мере именно в русской литературе.

Отказавшись от традиционной грамматики, поэт-футурист считал, что имеет право на свою орфографию и словотворчество; для него главное - не содержание, а форма стихосложения. Позиция, которую отстаивали русские футуристы: классика мертва, Пушкин непонятнее иероглифов, необходимо «сбросить» Пушкина, Достоевского, Толстого с парохода современности, провозгласив свое «самовитое» слово. Например, поэт-футурист А. Крученых писал так: «Дыр бул шил//убещур//скум//р лзз».

Произведения футуристов-литераторов определяются в результате современного филологического анализа как формы предъязыка и протоязыка ${ }^{5}$, то есть как результат деградации речи. Напомним, что речь является интегратором человеческой психики, переводящей ее на уровень сознания 6 . В ситуации деградации интегратора вся иерархия сознания может распадаться и любая из функций, сформировавшаяся в раннем онтогенезе, оказаться автономной и искаженной в результате регрессии.

Характеризуя последствия увлечения футуризмом, современный писатель С. Куняев описывает нравы, царящие в среде поэтов Серебряного века, так: «Обезбоженность, порой переходящая в открытое богохульство, успехи и достижения сексуальной революции, равнодушие, а порой и ненависть к семейным устоям, безграничное злоупотребление “правами человека”, культ греха и потеря инстинкта самосохранения привели Серебряный век к девальвации божественной ценности жизни, к душевной опустошённости его “продвинутых детей”, к потере смысла человеческого существования. В конечном счёте, самоубийство

${ }^{5}$ Титов М. В. «Новая» революция в русском языке // Вестник ТГУ. Гуманитарные науки. Филология. Вып. 8 (52). 2007. С. 276-280.

${ }^{6}$ Веккер Л. М. Психика и реальность. М., 1998. С. 614 
стало обычным явлением для “серебряной среды” . Станислав Куняев перечисляет имена десятков поэтов-футуристов, покончивших с собой. «Стал нашим хлебом цианистый калий» - писал Георгий Иванов о своих собратьях по перу.

Но вернемся к их вдохновителю - Маринетти, который менее известен как художник. Сначала его стилем была «аэроживопись», воспевавшая авиационную технику, затем «абстракция» и «кубофутуризм». С точки зрения периодизации развития изобразительных способностей его полотна представляли собой результат деградации сначала на стадию предметного, затем - объектного рисования, с преобладанием геометрических форм.

Возвеличивание агрессивности в искусстве сопровождалось тем, что Маринетти стал одним из основателей итальянского фашизма, сотрудничал с Муссолини, во время Второй мировой войны воевал на стороне Гитлера и был убит в 1944 г.

В книге Э. Фромма итальянскому футуризму посвящен отдельный параграф, в котором написано, что идеи Маринетти обеспечили ему «почетное местечко рядом с Муссолини и Гитлером» ${ }^{8}$, причем имелись в виду не политические взгляды этих людей, а их общая аномалия личности.

\section{Казимир Малевич. Супрематизм}

Казимир Малевич - первооткрыватель так называемого «русского авангарда», ныне его считают великим художником. Наиболее известные работы: «Чёрный квадрат» и «Супрематическая композиция».

В начале XX в. он никем еще не признан, некоторые авторы даже пишут, что Малевич не умел рисовать. Но это явное преувеличение, о чем говорят полотна в стиле импрессионизма: «Весенний пейзаж», «Белье на заборе», «На бульваре», «Цветочница» и др.

Затем под впечатлением кубизма Пикассо и кубофутуризма Маринетти он создает свой стиль - «русский кубизм»; это работы 1911-1912 гг. Первоначально в живописи Малевича прием, искажающий образ тела и черт лица, явно носил подражательный характер («Садовник», «Купальщик» и др.).

Позже появилась субъективная особенность: условно-обобщенное, схематизированное изображение человеческих фигур с «пустыми лицами», лишенными индивидуальности, напоминающими маску, в которой нет жизни, словно это не люди, а фарфоровые куклы («Голова крестьянской девушки», «Портрет строителя», «Девушки в поле», «Утро после грозы», «Женщина с ведрами», «Две мужские фигуры», «Три женские фигуры» и пр.). Эти картины Малевича соответствуют стадии единичных крупных предметных изображений, на которой человек схематичен и как бы собран из отдельных деталей.

Несколько позже произошло еще одно знаковое изменение: с его портретов совсем исчезли лица тех, кого он изображал; лица обозначались цветными или белыми пятнами, пришла безликость («Жатва», «Уборка ржи», «Провинция», «Крестьянки в церкви», «Крестьянка с ведрами и ребенком», «Крестьянка с вед-

\footnotetext{
${ }^{7}$ Куняев С. Любовь, исполненная зла. М., 2013.

${ }^{8}$ Фромм Э. Анатомия человеческой деструктивности. М., 1994.С. 294-296.
} 
М. Н. Миронова. Трансформация изобразительного искусства: субъективный взгляд...

рами»). Вероятно, был сделан еще один шаг вниз по ступеням изобразительности - на стадию объектного рисования, а именно в «точку» появления первых изображений человека - головоногов. У головоногов ребенка сначала нет черт лица, но постепенно появляются глаза, нос, рот и другие детали. У людей на портретах Малевича черты лица сначала были, но затем они как бы распадаются и исчезают. Далее (в обратном развитию порядке) следует снижение к началу стадии объектного рисования с ее геометрическими фигурами и цветом, где у ребенка даже головоногов пока еще не существует. Чему у Малевича соответствует период геометрических форм.

Может возникнуть возражение: во всех культурах и во все времена существовали формы прикладного искусства, содержащие абстрактные темы - треугольники, квадраты, зигзаги и другие орнаментальные рисунки; все они соответствуют достаточно ранней ступени развития изобразительной деятельности. Неужели и современные геометрические изображения должны определяться как деградация изобразительности?

Но эти прикладные формы существуют не самостоятельно, они - результат утилитарной деятельности, которая имеет свои собственные цели и смыслы. Геометрические фигуры выполняют эстетическую функцию, которая является здесь не самостоятельной, но служебной. А элементы художественных действий и операций, соответствующие геометрическому рисованию, - это чернорабочая сила другой деятельности, они подчинены соответствующим целям и смыслам как высшим образованиям сознания.

Малевич же много раз заявлял, что его искусство - вне идей целевых, это «чистое искусство», оно самоценно. В данном случае производится как бы отрыв изобразительности от каких-либо человеческих смыслов, которые обеспечат иерархию сознания. В контексте рассматриваемой теории «рабы рабов» неминуемо становятся самостоятельными, что провоцирует разворот вектора развития в сторону деградации.

Будучи человеком активным и разносторонне одаренным, Малевич создает теорию образа в живописи ${ }^{9}$, в которой он рационализирует то, что получается на холсте. Он утверждает, что сюжет, а также изображение лиц, на которых есть глаза и улыбка, убивают самое ценное в творчестве - цвет и фактуру живописной плоскости, которые должны быть в центре внимания. Своему направлению художник дает название «супрематизм», которое происходит от польского «супрематия», что означает главенство, превосходство, в случае живописи - доминирование основного цвета над всеми остальными компонентами. (Находясь под влиянием литературных идей футуризма, художник начинает работу «О новых системах в искусстве» стихами: «Я иду // У-эл-эль-ул-эл-те-ка // Новый мой путь» ${ }^{10}$. В дальнейшем эта заумь вошла в название его манифеста).

9 Здесь и далее: Малевич K. Собр. соч. в 5 т. Том 1. Статьи, манифесты, теоретические сочинения и другие работы. 1913-1929. М., 1995. Том 2. Статьи и теоретические сочинения, опубликованные в Германии, Польше и на Украине. 1924-1930. М., 1998. Том 3. Супрематизм. Мир как беспредметность, или Вечный покой. М., 2000. Том 4. Трактаты и лекции первой половины 1920-х годов. 2003. М., 2003. Том 5. Произведения разных лет. М., 2004.

${ }^{10}$ Малевич К. Статьи, манифесты, теоретические сочинения и другие работы. 1913-1929 // Собр. соч. в 5 т. М., 1995. Том 1. С. 149. 
Идея «Черного квадрата», согласно воспоминаниям самого художника, пришла к нему во время работы над постановкой оперы «Победа над Солнцем». Декорация одной из сцен представляла собой квадрат, поделенный на две части - черную и белую. По замыслу квадрат являл собой образ победы активного человеческого творческого начала над пассивной природой: черный квадрат против солнечного круга.

Несколько картин под названием «Черный квадрат» были написаны позже. Эти квадраты не так уж просты: во-первых, все они определенным образом деформированы; кажущиеся параллельными линии таковыми не являются, но это не определяется «на глаз». Во-вторых, краска наносилась на них тоже определенным образом. Например, белый фон, на котором расположен черный квадрат, является неоднородным по плотности нанесения краски. А черный цвет это результат нанесения на холст красок различного цвета. С психологической точки зрения можно думать, что плоды подобных экспериментов укладываются в понятие «подпороговое восприятие», с которым связаны многие эффекты, относящиеся к «загадочным явлениям» психики.

Именно «Черный квадрат» считается самым новаторским произведением художника, но Малевич не был первым. Несколько одноцветных прямоугольников (с этой точки зрения - супрематических картин) черного и красного цветов появлялись на выставках и ранее. Но они были лишь остроумными шутками. У Малевича же все серьезно: после создания своей главной работы он неделю не мог ни есть, ни спать, потому что был занят вглядыванием в загадочное черное пространство. И чувствовал себя приобщившимся к Вечности. Малевич в геометрических формах видел высшее начало всей реальности.

Но с психологической точки зрения вполне обоснованным является допущение о деградации изобразительной деятельности художника, вплоть до ее полной аннигиляции. Дело в том, что ниже объектной стадии находится предобъектная с ее хаотическими линиями. Быть может, она и представлена у Малевича и в более поздней «Супрематической композиции», только линии в ней выполнены более уверенной рукой, чем у ребенка. На пути деградации изобразительности это последний пункт, после которого изображения уже нет. И на холсте Малевича, и в его философии остается лишь некий пустой элемент, собственно пустота, которую он обозначает как Нуль, Ничто ${ }^{11}$, и ощущение «пустыни небытия», метафизической пустоты преследует художника. В супрематизме Малевича эффект «пожирания» образа мира оказался еще более завершенным, чем у Кандинского.

В его сочинениях можно встретить термины «беспредметность» и «безобразность», написанные через запятую. Но если «беспредметность» необходимо отнести к картине, то «без-образность», вероятно, уже к его собственному сознанию. Беспредметность на полотнах может приводить к дезинтеграции образного основания сознания художника, на котором оно зиждется и через которое развивается; к снижению, а не расширению сознания.

${ }^{11}$ Малевич К. Супрематизм. Мир как беспредметность, или Вечный покой // Собр. соч. в 5 тт. М., 2000. Том 3. С. 310. 
М. Н. Миронова. Трансформация изобразительного искусства: субъективный взгляд...

А если учесть, что онтогенетическое и историческое развитие в чем-то являются параллельными, то супрематизм - это еще и возвращение к одной из протоформ сознания. Соответственно, в своей теории Малевич доказывал правомерность возвращения к сущностному основанию бытия. Итак, художник стремится последовательно идти путем деградации не только изобразительности, но и бытия - к самому началу.

Протобытие и по космогоническим теориям, и по Священному Писанию действительно начиналось из хаоса и пустоты. Но возвращение к нему равносильно зачеркиванию результатов жизни человечества на Земле. А ведь Господь отправил на нее Адама для исправления последствий первородного греха: все приобретения сознания, сделанные в земной истории, в том числе и образы, должны служить для этой цели! Наиболее катастрофическим результатом деградации может оказаться блокирование образа Божия в человеке; искажение образа Другого, который тоже есть образ Божий; забвение памяти о том, что человек создан Творцом и должен после жизни в Мире вновь вернуться к Нему!

Но Малевич провозглашает, что он свободен от истории, что надо создавать Новую Вселенную, а себя называет Председателем Пространства(!), способным творить Новые Вселенные, для чего необходимо погружаться вглубь себя. Недаром же современные поклонники Малевича считают, что супрематизм есть своего рода прорыв К «новому», космическому сознанию.

Подобные идеи мы найдем в учениях эзотериков прошлого, в оккультизме и даосизме ${ }^{12}$. С точки зрения христианства Малевич попадает в ловушку: путает незрелое человеческое сознание со сверхчеловеческим ${ }^{13}$. Эта ловушка типична для оккультизма. Для него характерно выворачивать наизнанку традиционные понятия и ценности, менять добро и зло местами, стремясь в будущее, увязать в прошлом, попирать то, что всегда было нормой, горделиво думать, что открылась истина в последней инстанции. Убедиться в богоборческом характере этих «истин» можно, например, из оценки Малевичем православной иконы: «Икона как таковая малокультурное варварство, темное поклонение перед ней умаляет» ${ }^{14}$. Истинная же икона - это «Черный квадрат» ${ }^{15}$.

Возвращаясь вновь к психологической диагностике и «Черному квадрату», уточним, что обычно при интерпретации результатов графических тестов солнце на рисунке означает свет, тепло, благо, добро и говорит о благополучии развития. Черный цвет в рисунке является маркером неблагополучия. Но у Малевича своя символика. Его идея о том, что черный цвет - это олицетворение активного человеческого творчества, а солнце - пассивной природы, противоречит традиционным историческим и религиозным представлениям об этих символах. В другом же месте художник, вновь переворачивая смыслы, называет черный квадрат воплощением жизни и противопоставляет его прежней живо-

${ }^{12}$ Ичин К. Супрематические размышления Малевича о предметном мире // Вопросы философии. 2011. № 10. С. 48-56.

${ }^{13}$ Генон Р. Традиция и бессознательное // Вопросы философии. 1991. № 4. С. 51-53.

${ }^{14}$ Малевич К. Супрематизм... С. 62.

${ }^{15}$ Малевич о себе. Современники о Малевиче. Т. 1. Письма. Документы. Воспоминания. Критика / И. А. Вакар, Т. Н. Михеенко, сост. М., 2004. С. 84-85. 
писи - «мертвописи». У Малевича подобные перевороты, которые в некоторых оккультно-философских системах порой существуют в скрытом виде, проступают весьма явно.

То, что победа «Черного квадрата» над солнцем в традиционной, «прямой», неискаженной символике означает гибель мира, ярко почувствовал А. Бенуа: «Черный квадрат в белом окладе - это не простая шутка, не простой вызов... а это один из актов самоутверждения того начала, которое имеет своим именем мерзость запустения и которое кичится тем, что оно через гордыню, через заносчивость, через попрание всего любовного и нежного, приведет всех к гибели» ${ }^{16}$.

Существует гипотеза о том, что полотна Малевича - это средства для медитации. Один из современников художника утверждал, что «Черный квадрат» — это буддийская религиозная эмблема. А автор хрестоматии по эстетике В. В. Бычков писал, что работы Кандинского и Малевича могут служить объектами медитации и посредниками в духовных практиках ${ }^{17}$. Отсюда следует, что их картины, так же как и остальные формы медитации, определенным образом воздействуют на зрителя - изменяют уровень сознания. Предположение подтверждается и тем, что, работая, Малевич медитировал сам. Как вспоминала родственница второй жены Малевича, Евгении Рафалович, когда он работал, «пел» один и тот же мотив «Тумба-тумба, тумба-тумба...», состоявший из четырех нот: «до-до pe-pe - ля-ля - до-до». Известно, что подобные бессмысленные, многократно повторяющиеся ритмы вводят в трансовые состояния сознания.

Для таких погружений в восточных религиях используют многие средства, в том числе гипнотроны и так называемые «мандалы» - геометрические формы, в результате перцепции которых воспринимающий входит в измененное состояние сознания. Считается, что такие упражнения - путь к духовному развитию (на востоке геометрические фигуры считались священными). Поэтому картины Малевича выполняют ту же функцию, что и мандалы. Художник, сам находясь в состоянии транса, создавал картины, с помощью которых зрители могли бы войти в то же самое состояние. Когда он хотел показать зрителям «бесконечность и вечность», то рекомендовал долго, сосредоточенно смотреть прямо в середину квадрата, не отвлекаясь ни на что, и тогда, в конце концов, «начнешь это чувствовать».

Но, с точки зрения психологии это один из приемов, усыпляющий человека, активирующий архетипы бессознательной сферы. В норме у современного человека архетипы должны быть заблокированы (В. И. Слободчиков)! Из психофизиологии известно, что энцефалограмма медитирующих людей изменена. В ней у начинающих адептов доминируют альфа-ритмы, но после длительных упражнений картина меняется - доминируют дельта- и тета-ритмы ${ }^{18}$. Такая же энцефалограмма снимается у психически больных людей и наркоманов, с этой точки зрения созерцание мандалы - способ, отнюдь не расширяющий, но сни-

${ }^{16}$ Цит. по: Толстая T. Река Оккервиль. М., 2002. (URL: http://royallib.com/book/tolstaya_ tatyana/reka_okkervil.html).

${ }^{17}$ Бычков В. В. Эстетика. М., 2002.

${ }^{18}$ Марютина Т. М., Ермолаев О. Ю. Введение в психофизиологию. М., 2001. 
М. Н. Миронова. Трансформация изобразительного искусства: субъективный взгляд...

жающий уровень сознания, негодный для обретения духовности в том понимании, которое существует в Православии!

После периода супрематизма Малевич заболевает психическим расстройством $^{19}$. Случайна ли болезнь с точки зрения излагаемых здесь представлений или она - следствие супрематизма? Для того чтобы задать такой вопрос, есть основания: «Когда объективные значения окружающего мира и те смыслы, в которых этот окружающий мир человеку преломляется, находятся в отношениях чуждости, несовместимости друг с другом - возникает явление дезинтеграции сознания» ${ }^{20}$

Так или иначе, Малевича постигла страшная участь, но в редкие минуты просветленности сознания он написал, что тайна «Черного квадрата» - это «чернота, пустота, ад». Об этом не пишут искусствоведы, а ведь именно это свидетельство наиболее ценно.

В конце концов в 30-х гг. Малевич отказывается от супрематизма, и в его творчестве совершается разворот вновь к изобразительности. Далее следуют периоды традиционной живописи («Портрет дочери», «Портрет жены» и др.) и периоды «провалов» к ранним стадиям изобразительных способностей. В этом смысле особенно выраженной оказывается манера, аналогичная примитивному рисованию, которое у ребенка связано с моментом появления первых головоногов, у которых лица только постепенно появляются; прорисовывается туловище (овалы, треугольники, прямоугольники), одежда, а в руках - различные предметы. И у Малевича после супрематизма (1928-1932 гг.) черты лица на картинах тоже постепенно появляются («Девушки в поле», «Портрет мужчины», «Жница», «Урожай», «Сенокос», «Крестьянин в поле», «Женщина с граблями» и др.). А далее ярко проявляется искаженная детская стадия единичных крупных предметных изображений с ее схематическими рисунками, для которой характерно особое значение цвета, деталей, одежды, предметов в руках («Девушка с палкой», «Девушка с гребнем», «Портрет женщины»). Еще одна интересная особенность, относящаяся к схематическому рисунку: человек здесь как бы собран из отдельных деталей, подобное впечатление достигается за счет изображения одежды, в которой все детали собраны из отдельных частей различного цвета. (Конечно же, у Малевича, обладающего взрослой рукой, схематичность не полностью тождественна детской). Характерны и схема дома на его картине после супрематизма («Красный дом»): здесь отсутствует множество элементов, и полотна «Прачка», «Плотник», «Дачник». Но полной реабилитации изобразительности после супрематизма не произошло, что соответствует принципу необратимости регрессии.

Вот что писал один из критиков о картинах этого периода: «Все его попытки выйти на путь настоящего реалистического искусства, вроде его картины “Девушка с красным древком” (1932), выдают только беспомощность художника.

${ }^{19}$ Гаспаров М. Записи и выписки. М., 2007.

${ }_{20}$ Леонтьев А. Н. К психологии образа // Вестник Московского Университета. Серия 14. Психология. 1986. № 3. С. 72-76. 
Творческая судьба ряда русских “левых” художников воочию показывает, как абстракционизм губит талант художника» ${ }^{21}$.

Возможно, сказано безжалостно и кто-то с этим выводом не согласен, но критик понял психологическую тенденцию.

В последние годы художник занимался прикладными формами. Он использовал геометрические фигуры в эскизах росписей тканей, посуды, в моделировании одежды, архитектурных проектах. Теперь современные дизайнеры «в духе Малевича» оформляют интерьеры зданий, обложки книг, тару и упаковку товаров и пр. Но как бы масштабны и значительны эти разработки ни были, они вновь пример снижения уровня изобразительного искусства.

До сих пор «Черный квадрат» является предметом острых дискуссий и противоречивых суждений. И если А. Бенуа говорил когда-то только о «Черном квадрате» и футуристах: «Несомненно, это и есть та икона, которую господа футуристы ставят взамен Мадонны», то теперь звучит это более современно: «бренд». Но не тот ли это случай, когда: ... ито высоко среди людей, то мерзость пред Богом (Лк 16. 15)?

Как же нам оценивать творческое наследие художника? Сошлемся на слова Святейшего Патриарха Кирилла о том, что не будь квадрата Малевича, мы не могли бы понять, что творилось в начале XX в. Но сравниваем Владимирскую икону Божией Матери с Малевичем, нам все становится ясно 22.

\section{Марсель Дюшан. Дадаизм}

Название этого течения прямо указывает на его регрессионный характер, так как «dada» по-французски - детская деревянная лошадка. Рационализация стиля заключалась в обосновании протестного разрыва с традиционной культурой, отрицании всех ценностей, представлении о мире как о хаосе, которому дадаисты стремились противопоставить хаос своего сознания. Они шокировали публику, устраивали скандалы не ради достижения каких-то целей, а ради собственно скандалов, что соответствует поведению маленьких детей, которые иногда стремятся добиться внимания взрослых отвратительными поступками, визжа и падая на пол.

Среди дадаистов следует выделить Марселя Дюшана, который сначала писал пейзажи и жанровые полотна в стиле импрессионизма, постимпрессионизма и фовизма («Мужчина у окна», «Портрет отца», «Прачечная-баржа»), затем кубизма («Портрет шахматистов», «Грустный молодой человек в поезде», «Обнаженная, спускающаяся с лестницы»). Но работал мало, гораздо более его занимало участие в эпатажных акциях. Затем он выполнил абстрактную картину на стекле: «Новобрачная, разоблаченная самими холостяками, или Большой стакан». Известна и его скандальная копия «Джоконды» с усами и бородой.

${ }^{21}$ Стойков A. Критика абстрактного искусства и его теорий. M., 1964. (URL: http://www. artvek.ru/iskusstvo/kritika06.html).

${ }^{22}$ В ходе дискуссии на Архиерейском совещании 2 февраля 2015 года. URL: http://ruscur. ru/news/0/07/73/77376.shtml. (дата обращения :17.04.2017). 
М. Н. Миронова. Трансформация изобразительного искусства: субъективный взгляд...

Однако затем Дюшан перестал писать картины и стал показывать на выставках «реди-мейд» (англ. «готовое изделие»), то есть предметы промышленного производства, купленные в магазине. Так, в 1912 г. он выставил лопату для уборки снега с вырезанной на рукоятке фразой «Аванс за сломанную руку», далее было показано самое значительное с позиции трансформации искусства «произведение» - фаянсовый писсуар, названный «Фонтаном». После этого Дюшан прекратил заниматься творчеством на тридцать лет. После 1946 г. разработал концепцию современного искусства, согласно которой зритель играет в создании произведения столь же активную роль, как и художник, которая в настоящее время эксплуатируется.

Последние двадцать лет жизни Дюшан работал над инсталляцией «Etant Donnes (дверь)», смысл которой малопонятен, но наличие в ее структуре копии картины классического стиля может говорить о том, что это была своеобразная попытка развернуть вектор развития в прежнее, нормальное направление.

Вероятно, и в случае Дюшана мы можем говорить о последовательности динамики регрессии изобразительной деятельности со стадии событийного на стадии объектного и примитивного рисования. Но чем обусловлено появление «реди-мейд» - полной ли деградацией изобразительности, либо это действие «от ума» с целью эпатажа - сказать доподлинно трудно. Есть сведения и о возможной третьей версии: у художника были проблемы с психикой, из-за которых он не смог служить в армии.

Но в любом случае можно думать о нарушении нравственной регуляции деятельности Дюшана. Для дадаистов было принято вызвать шок, эпатировать публику, последнее могло привести к сдвигу мотива на цель, формирующейся аномалии личности ${ }^{23}$. Если вначале мотивом являлось привлечение внимания публики, а целью конкретного мероприятия - эпатаж, то вскоре мотивом становится собственно эпатаж, стремление шокировать окружающих на уровне страсти.

Тем не менее идеи Дюшана оказали влияние на дальнейшее формирование сюрреализма и на такие направления в искусстве второй половины XX в., как попарт, минимализм, динамизм, концептуализм, на все «новое искусство» XXI в.

\section{Выводы}

Наш анализ показал, что в творчестве всех шестерых первооткрывателей авангарда обнаруживается последовательная динамика трансформации художественного стиля, обратная нормальному порядку развития художественных способностей ребенка.

Пятеро из художников (А. Матисс, В. Кандинский, П. Пикассо, К. Малевич, М. Дюшан) начали свой творческий путь с подражания модерну или постимпрессионизму, которые использовали технику несколько примитивного изображения (соответствующего событийному рисованию ребенка). От предшественников они заимствовали отказ от традиционного пути развития художественного творчества и убеждение в том, что искусство должно вызывать прежде

\footnotetext{
${ }^{23}$ Братусь Б. С. Аномалии личности. М., 1988. С. 175-193.
} 
всего эмоциональную реакцию. Таким образом, они получили своеобразную предпосылку к регрессии. Далее деградация неотвратимо усугубилась, так как «субъект в своих деяниях... созидается и определяется» ${ }^{24}$.

На полотнах всех шестерых художников присутствует искажение или исчезновение образов мира и Другого. Эти особенности могут пониматься как снижение уровня смысловой вертикали сознания, падение с «Лествицы», изображенной на иконе, что могло быть возможной причиной различных форм нарушения психологического здоровья у пятерых из шести художников.

Для четырех художников в зрелом возрасте был характерен отказ от регрессивных тенденций (В. Кандинский, К. Малевич, П. Пикассо, М. Дюшан) и попытка реабилитации изобразительных способностей.

Все шестеро первооткрывателей авангарда были натурами деятельными, обладающими способностью влиять на умы, они философствовали, читали лекции, писали книги, создавали свои школы, увлекали идеями товарищей по цеху и зрителей, оказывая существенное воздействие на последующие жанры и направления авангарда.

Получив в наследство от более ранних новаторских направлений регрессию всего лишь в стадии событийного рисования, они совершили стремительный спуск по ступеням художественных способностей до самой низшей (онтогенетически первой), оставив в наследство «новому искусству» XXI в. интенцию к деградации и художественную деятельность без изобразительности.

\section{Искусство, изжившее живопись}

В современных галереях место живописи все более и более сводится к минимуму и на смену ей уверенно приходят более современные формы. Не зря К. Малевич в своем манифесте пророчески провозглашал: «Живопись давно изжита». Путь «живописного нуля» продолжили многочисленные направления арт-деятельности, отказавшиеся от кистей, красок, холста.

Самая востребованная форма «нового искусства» - инсталляции (от англ. to install - устанавливать). Их устанавливают, составляют, формируют из отдельных частей; они создаются из самых различных элементов - бытовых предметов, промышленных изделий и материалов, природных объектов, текстовой или визуальной информации, пищевых продуктов. В этом жанре активно реализуется концепция Дюшана об авторстве зрителей. Так, один из художников выставил в павильоне штабель из деревянных брусков, чтобы каждый посетитель, сложив из них все, что придет в голову, мог приобщиться к искусству. Еще одна новейшая форма современного искусства - перфо́рманс (англ. performance - исполнение, представление, выступление). Перформанс отличается от инсталляции тем, что элементом произведения становится сам художник, его тело или его действия; сердцевина перформанса - эпатаж, провокационность.

${ }^{24}$ Рубинштейн С. Л. Принцип творческой самодеятельности // Избранные психологические труды. М., 1997. С. 438. 
М. Н. Миронова. Трансформация изобразительного искусства: субъективный взгляд...

Есть еще акционизм, который является логическим продолжением перформанса. Акция - это действие, направленное на достижение какой-либо цели, часто деструктивной. Так, в начале июня 2013 г. в Перми проводилась акция под названием «ОккупайПермь», по аналогии с московским «ОккупайАбай». Посетителям предлагалось: пожить в палатках, пожечь покрышки, поупражняться в протестных властям действиях. Акция стирает грань между искусством и действительностью.

Существуют и другие необычные жанры, но остановимся на перечисленных.

Мы предполагаем, что в основе «нового искусства» постмодерна лежит все та же тенденция к деградации, но проявляющаяся преимущественно в других сферах сознания: как регрессия воображения, творчества и нравственной регуляции деятельности.

Ключом к пониманию того, что такое инсталляция с психологической точки зрения послужила одна весьма показательная работа с выставки: башмак, вставленный в корпус старого телевизора. Это произведение искусства являло собой модель, воспроизводящую психологический механизм бинарных операций, или дипластий, или бисоциаций ${ }^{25}$.

Бисоциация (дипластия, бинарная операция) - это комбинация из двух предметов, образов или идей, взятых из разных контекстов, ранее казавшихся несовместимыми. Получается нечто третье - новое, чего ранее не существовало. Есть еще понятия «трипластии» и «тетрапластии» - соединение дипластий. Все они являются последовательными ступенями в формировании воображения у ребенка, а затем на его основе развиваются мышление, речь, творчество, юмор, гармония (одно из значений: согласие принципиально разногласного), в конце концов, на вершине духовного развития - антиномия. Но уточним: в соответствии с принципом иерархичности развития в более поздних и совершенных образованиях бисоциации не должны иметь самостоятельности. Бисоциация только одна из составляющих воображения, его «ранний» элемент (детский, низший в иерархии сознания). В творческом процессе зрелой личности воображение, в свою очередь, само является чернорабочей силой; оно уже не может быть свободным, должно быть «вплетено» в более совершенные образования, работать ради высоких целей и смыслов, не может обойтись без нравственной регуляции. У бисоциации же подчинение двойное, она - «раб рабов» творчества.

Бисоциация, освободившаяся в результате регрессии из-под управления высшими структурами, извращается, становится лишь нелепостью или абсурдом. Инсталляции с этой точки зрения - продукт выпавших из иерархии творчества и испортившихся бисоциаций, абсурд в «чистом виде», ставший главным предметом «нового искусства».

Бракованные бисоциации, вырванные из иерархии творчества и превращенные в абсурд, эксплуатировались еще футуристами. В их среде родилась так называемая «заумь», которая выражалась нарочито прямолинейным совмещением несовместимых вещей в поэзии и в изобразительности. Малевич тоже поработал

${ }^{25}$ Wallon A. Les origines de la pensee chez l'enfant. Paris, 1945, Т. 1-2; Поршнев Б. Ф. О начале человеческой истории. М., 1974; Koestler A. The Act of creation. London, 1964. 
в этом жанре, наложив изображение коровы на скрипку («Корова и скрипка», 1913); храма, селедки, свечи, сабли, лестницы - на лицо человека («Англичанин в Москве», 1914). Но первым был М. Дюшан, совместивший произведение искусства и промышленное изделие.

В свое время А. Кёстлер предложил использовать упражнения в сочетании несочетаемого для развития креативности. К сожалению, этот талантливый автор не учел принципов иерархичности и необратимости развития. В результате незначительной теоретической ошибки у практиков появился соблазн посредством тренировки в абсурде формировать таланты ${ }^{26}$. (Если бы дело обстояло так просто, то производство гениев уже было бы поставлено на поток.)

Подлинное творчество всегда боговдохновенно, в таком сотворчестве то, что необходимо соединить и с чем именно соединять, подсказывает Бог. В фальшивой же креативности - подсказчик, скорее всего, иной (кто именно, религиозным людям хорошо известно).

Но наиболее существенная характеристика абсурда - он не регулируется смысловыми структурами нравственной регуляции личности. Поэтому под видом юмора карикатуристами попирались святыни, а инсталляции создавались не только из поленьев, унитазов, чучел животных, но и из трупов людей, хранящихся в формалине!

Из изложенного следует, что производство абсурда в случае искусственно стимулируемого воображения требует впоследствии выбраковывания недопустимых с точки зрения этики произведений-нелепостей, которые являются результатом незрелого, зеленого и кислого на вкус плода недотворчества. Противоречит ли это свободе художника?

Сравните: «Свобода - всего лишь негативная (обратная) сторона цельного понятия, позитивной (лицевой) стороной которого является ответственность. Действительная свобода может выродиться в простой произвол, если она не ограничена ответственностью» ${ }^{27}$. Наивысшей инстанцией, пред которой человек несет ответственность, В. Франкл называет Бога.

Подлинная свобода творчества, которой Бог наделил человека, - это возможность творить в гармонии с Истиной, Добром и Красотой в противовес обстоятельствам, какими бы они ни были. Но в «новом искусстве» под свободой понимается вседозволенность, безответственность и произвол. С психологической точки зрения требование подобной свободы - подростковая реакция, еще один пример деградации или инфантилизма. Для формирования подобной свободы разработаны психотехники, которые предполагают соискателям креативности не только упражнения, активирующие воображение (точнее - механизм абсурда), но и тренинги, «снимающие рамки». Ключевой момент таких занятий - раскрепошение, снятие запретов, «тормозов» (из объявления: «...зритель приглашается напрямую участвовать в приостановке традиционной морали»). А один из видов «нового искусства» - «абстрактный экспрессионизм» - характеризуется как «жест освобождения от ценности политической, эстетической, моральной». Со «снятием рамок» часто связан и перформанс.

\footnotetext{
${ }^{26}$ Бос Э. Как развивать креативность. Ростов-на-Дону, 2008.

${ }^{27}$ Франкл В. Человек в поисках смысла. М., 1990.
} 
М. Н. Миронова. Трансформация изобразительного искусства: субъективный взгляд...

Отзыв случайного участника одного из перфомансов: «Недавно был вечер, на котором всем входящим давали ведро с краской, чтобы люди друг друга мазали. А потом среди людей проехала лошадь с голой девкой-наездницей. Это обставлялось как жуткое новаторство в искусстве. Может, я просто наркотики никогда не пробовал и поэтому ничего не понимаю?»

«Рамки» на человека налагает нравственная регуляция деятельности, которая в психофизиологической сфере направлена на формирование доминанты торможения (А. А. Ухтомский, Б. Ф. Поршнев). Торможение является активным физиологическим процессом, причем гораздо более энергозатратным и зрелым, более поздним в онтогенезе, чем возбуждение.

Раскрепощение, снятие запретов - это срыв торможения, который приводит к преобладанию возбуждения, приливу энергии, что бодрит, поэтому человек стремится испытать такое состояние вновь и вновь. При постоянных раскрепощениях доминанта торможения деградирует, нравственность - вместе с ней! Психология в этом случае может указать на такую форму регрессии, как примитивизация - переход на более примитивный уровень социального взаимодействия или на возврат к формам поведения, которые были свойственны животным. Святые отцы тоже знали, что человек может «оскотиниться». Поэтому перформансы с раскрепощением - это эффективный способ деградации личности. Своей, если говорить о тех, кто создает «новые произведения», и тех, кто является реципиентом.

В результате художник-постмодернист способен пригвоздить свои гениталии к брусчатке Красной площади. Другой - резать свинью, на боках которой написано «Россия», на куски, еще один - рубить православные иконы топором.

Думается, что традиционные для научной статьи выводы о «новом искусстве» излишни, более уместными будут слова о нем религиозного автора: «... это искусство недочеловеческое, демоническое. Предметом этого искусства является не человек, но некое низшее существо, поднявшееся..., «вышедшее» из неведомых глубин... Новое искусство празднует рождение нового вида, существа из самых глубин, недочеловека» ${ }^{28}$.

Ключевые слова: «новое искусство», изобразительная деятельность, деградация, образ Другого, образ мира, бинарные операции, абсурд.

\section{Список литературы}

Аксенова Ю. А. Символы мироустройства в сознании детей. Екатеринбург, 2000. Бос Э. Как развивать креативность. Ростов-на-Дону, 2008.

Братусь Б. С. Аномалии личности. М., 1988.

Бычков В. В. Эстетика. М., 2002.

Веккер Л. М. Психика и реальность. М., 1998.

Гаспаров М. Записи и выписки. М., 2007.

Генон Р. Традиция и бессознательное // Вопросы философии. 1991. № 4. С. 51-53.

Ичин K. Супрематические размышления Малевича о предметном мире // Вопросы философии. 2011. № 10. С. 48-56.

\footnotetext{
${ }^{28}$ Серафим (Роуз), иером. Человек против Бога. М., 1995. С. 75-76.
} 
Куняев С. Любовь, исполненная зла. М., 2013.

Леонтьев А. Н. К психологии образа // Вестник Московского Университета. Серия 14 Психология. 1986. № 3. С. 72-76.

Лотман Ю. М. Лекции по структурной поэтике // Ю. М. Лотман и тартусско-московская семиотическая школа. М., 1994. С. 37.

Малевич K. Собр. соч. В 5 т. Том 1. Статьи, манифесты, теоретические сочинения и другие работы. 1913-1929. М., 1995. Том 2. Статьи и теоретические сочинения, опубликованные в Германии, Польше и на Украине. 1924-1930. М., 1998. Том 3. Супрематизм. Мир как беспредметность, или Вечный покой. М., 2000. Том 4. Трактаты и лекции первой половины 1920-х годов. 2003. М., 2003. Том 5. Произведения разных лет. М., 2004.

Малевич о себе. Современники о Малевиче. Т. 1. Письма. Документы. Воспоминания. Критика / И. А. Вакар, Т. Н. Михеенко, сост. М., 2004.

Марютина Т. М., Ермолаев О. Ю. Введение в психофизиологию. М., 2001.

Поршнев Б. Ф. О начале человеческой истории. М., 1974.

Рубинштейн С. Л. Принцип творческой самодеятельности // Избранные психологические труды. М., 1997. С. 438.

Рубинштейн С. Л. Человек и мир. М., 1997.

Серафим (Роуз), иером. Человек против Бога. М., 1995.

Стойков А. Критика абстрактного искусства и его теорий. М., 1964.

Титов M. B. «Новая» революция в русском языке // Вестник ТГУ. Гуманитарные науки. Филология. Вып. 8 (52). 2007. С. 276-280.

Толстая T. Река Оккервиль. М., 2002.

Франкл В. Человек в поисках смысла. М., 1990.

Фромм Э. Анатомия человеческой деструктивности. М., 1994.

Koestler A. The Act of creation. London, 1964.

Wallon A. Les origines de la pensee chez l'enfant. Paris, 1945, T. 1-2.

\section{Transformation of Fine Arts: A Subjective View from the Perspective of Post-Non-Classical Psychology Focused on Christian Anthropology}

\section{Mironova}

The paper, proceeding from the framework of post-non-classical, Christian-oriented psychology, raises the problem of psychological aspects of transformation of fine arts and tries to identify its underlying cause. The most significant transformation is associated with avant-garde. The paper analyses dynamics in the change of graphic 
М. Н. Миронова. Трансформация изобразительного искусства: субъективный взгляд...

style of creative work of several artists standing at the origin of avant-garde, and shows that these dynamics generally correspond to the reverse order of developing graphic skills of children. Such forms of new art as installation, performance and actionism are analysed as well. It is considered that the dynamics of their transformation correspond to the reverse order of development of imagination of the child back to the earliest stage. This stage is characterised by binary operations that tend to be distorted as a result of degradation to absurdity and nonsense. The application of the traditional psychological principle of development can hardly give any definite evaluation of these phenomena; there is no answer to the question in what direction and for what reason the person has to develop, the main point being that he or she should be changing and doing something new. However, this problem can be solved in psychology which is oriented towards Christian anthropology. Any degradation is moving away from God.

Keywords: new art, graphic activity, degradation, image of the other, image of the world, binary operations, absurdity.

\section{References}

Aksenova Iu. A., Simvoly miroustroistva v soznanii detei, Ekaterinburg, 2000.

Bos E., Kak razvivat' kreativnost', Rostov-naDonu, 2008.

Bratus' B. S., Anomalii lichnosti, Moscow, 1988.

Bychkov V. V., Estetika, Moscow, 2002.

Frankl V., Chelovek v poiskakh smysla, Moscow, 1990.

Fromm E., Anatomiia chelovecheskoi destruktivnosti, Moscow, 1994.

Gasparov M., Zapisi i vypiski, Moscow, 2007.

Genon R., Traditsiia i bessoznatel'noe, in: Voprosy filosofii, 1991, 4, 51-53.

Ichin K., Suprematicheskie razmyshleniia Malevicha o predmetnom mire, in: Voprosy filosofii, 2011, 10, 48-56.

Koestler A. The Act of creation. London, 1964.

Kuniaev S., Liubov', ispolnennaia zla, Moscow, 2013.

Leont'ev A. N., K psikhologii obraza, in: Vestnik Moskovskogo Universiteta. Seriia 14. Psikhologiia. 1986, 3, 72-76.

Lotman Iu. M., Lektsii po strukturnoi poetike, in: Iu. M. Lotman i tartussko-moskovskaia semioticheskaia shkola. Moscow, 1994, 37

Malevich K., Sobr. soch. V 5 tt., Tom 1. Stat'i, manifesty, teoreticheskie sochinenija i drugie raboty. 1913-1929. Moscow, 1995. Tom 2. Stat'i $i$ teoreticheskie sochinenija, opublikovannye v Germanii, Pol'she i na Ukraine.
1924-1930. Moscow, 1998. Tom 3. Suprematizm. Mir kak bespredmetnost', ili Vechnyj pokoj. Moscow, 2000. Tom 4. Traktaty i lekcii pervoj poloviny 1920-h godov. 2003. Moscow, 2003. Tom 5. Proizvedenija raznyh let. Moscow, 2004.

Malevich o sebe. Sovremenniki o Maleviche. T. 1. Pis'ma. Dokumenty. Vospominaniia. Kritika, ed. I. A. Vakar, T. N. Mikheenko, Moscow, 2004.

Mariutina T. M., Ermolaev O. Iu., Vvedenie v psikhofiziologiiu, Moscow, 2001.

Porshnev B. F., O nachale chelovecheskoi istorii, Moscow, 1974.

Rubinshtein S. L., Printsip tvorcheskoi samodeiatel'nosti, in: Izbrannye psikhologicheskie trudy. Moscow, 1997, 438.

Rubinshtein S. L., Chelovek i mir, Moscow, 1997.

Serafim (Rouz), ierom, Chelovek protiv Boga, Moscow, 1995.

Stoikov A., Kritika abstraktnogo iskusstva i ego teorii, Moscow, 1964.

Titov M. V., «Novaia» revoliutsiia v russkom iazyke, in: Vestnik TGU. Gumanitarnye nauki. Filologiia, 2007, 8 (52), 276-280.

Tolstaia T., Reka Okkervil', Moscow, 2002.

Vekker L. M., Psikhika i real'nost', Moscow, 1998.

Wallon $A$. Les origines de la pensee chez l'enfant. Paris, 1945, T. 1-2. 